\title{
The Toronto Renaissance and Reformation Colloquium: An Independent Intellectual Forum at Fifty Years
}

\author{
ELIZABETH S. COHEN \\ York University
}

JANE COUCHMAN

Glendon College, York University

\section{Beginning}

$I^{n}$ 1963 two young scholars, Natalie Zemon Davis and James K. McConica, met at a session of the North Central Conference of the Renaissance Society of America (RSA), and in 1964 they became colleagues in the classroom at Atkinson College, the innovative night school in the new York University. As Davis and McConica talked of the intellectual community that they, both newcomers to Toronto, sought to support their scholarship, the Toronto Renaissance and Reformation Colloquium (TRRC) was born. In 2014, the TRRC celebrates fifty years as an independent, interdisciplinary forum that brings together scholars and students with broad and lively interests in the cultures of early modernity across Europe, and even beyond. As an integral part of a larger Renaissance and Reformation initiative in Toronto, the Colloquium from its start gave a diverse local community space to talk, learn from one another, and develop new ideas. Interdisciplinarity and comparative approaches-including what is now called "transnationality"-were always welcome. ${ }^{1}$

In the era before computers, email, and the Internet, volume 1, number 1 of the Toronto Renaissance and Reformation Bulletin-mimeographed,

\footnotetext{
1. This essay is based in good part on archival materials, paper and electronic, held at different sites at Victoria University in the University of Toronto. Important among these are the Centre for Reformation and Renaissance Studies and the Pratt Library, with their holdings of early issues of the TRRC Bulletin, and the Victoria University Archives with holdings that include TRRC minutes, correspondence, and other documentation. The authors are very grateful to Milton Kooistra for his help in reviewing these archives and organizing much scattered information into usable order. We also thank William Bowen as editor of Renaissance and Reformation/Renaissance et Réforme for funding this research assistance.
}

Renaissance and Reformation / Renaissance et Réforme 37.3, Summer / été 2014 
with a carefully hand-lettered title-circulated in October $1964 .{ }^{2}$ It promised to "appear sporadically with news of interest to Toronto scholars working in the fields of the Renaissance and Reformation." Readers were directed to send any news to "N. Z. Davis, Department of Political Economy, University of Toronto." At the bottom of the first page, the Bulletin reported the "Happy News" that "A Center [sic] for Reformation and Renaissance Studies is being formed at Victoria on the Toronto campus. The aim is to build up a modest but attractive research library." The central portion of the front page was given to a calendar of events to be held in Toronto during the fall. It listed eleven performances, exhibitions, and lectures of interest, including a Goldoni play in Italian, Machiavelli's Mandragola performed in English, a concert by the Deller Consort, a talk by art historian Francis Haskell in conjunction with a Canaletto exhibition at the "Toronto Gallery of Art," and, upcoming, a series of four lectures by renowned scholar Étienne Gilson on "The Birth of the Lutheran Reformation."

In parallel with these rich opportunities, the Bulletin's calendar also announced two meetings of the TRRC. On Friday 30 October, there was to be an informal luncheon at the Faculty Club, an initial call to gather the like-minded. And on Friday 4 December, a "first dinner meeting" of the TRRC, again at the Faculty Club, would hear Clifford Leech (English) ${ }^{3}$ speak on Christopher Marlowe's use of French history in his play The Death of the Duke of Guise or The Massacre at Paris. Details about the time for that event "will be mailed." For March 1965, a later issue of the Bulletin announced dinner with a talk by Kyle Sessions (Huron College, University of Western Ontario) on "The Hymn and the School: A Problem in Social Movement of the Lutheran Reformation." And, later that year, C. M. Kortepeter (Islamic Studies) was to speak on "The Renaissance and Reformation in the Ottoman Empire."

For several years the mix of lunch and dinner meetings continued, with speakers on an eclectic range of topics. In 1966 TRRC assembled for four dinners with talks by professors from the Universities of Toronto, Waterloo, and Guelph. In 1969 there were five dinner meetings, including one addressed by J. B. Trapp,

\footnotetext{
2. As the article on the journal in the present anniversary issue makes clear, the first issue of the TRRC Bulletin was also the first of R\&R. This document is reprinted in full on p. 50-52, above.

3. Speakers identified by department or program only may be understood to belong to the University of Toronto. Most speakers affiliated with other universities or colleges are identified by institution.
} 
librarian of the Warburg Institute, on the "The Poet and His Moment." ${ }^{4}$ During its first five years, the TRRC also heard talks on the Portuguese epic, law and literature in sixteenth-century France, the Scottish commercial middle class, Petrarchism and anti-Petrarchism, the Inns of Court, Tasso and Sidney, music and science, and Italian drama.

In 1970, when Germaine Warkentin agreed to serve as Vice-Chair of the TRRC, she suggested that the costly dinners be "cut out" and the meetings "moved to a slot later in the evening with wine and biscuits." It is not clear whether the after-dinner slot was ever tried. Certainly, in that time of university expansion and comparative governmental largesse, the dinner meetings continued for several more years. At a dinner in October 1971, TRRC founder Davis took up the gendered dimensions of the Reformation in a brand new way: "Urban Women in the French Reformation." Following another supper in spring 1972, TRRC founder McConica offered a fresh social approach to the history of education: "Tudor Universities in Tudor Society." In 1972-73, C. Edward Rathé (French, York) convened TRRC meetings on the York University Downsview campus. Among the speakers was historian Paul Grendler on the Roman Inquisition and the Venetian press. Some longtime members still recall braving a snow storm to attend one meeting at the Downsview campus; finding the lecture room door locked and no one on site to open it, the Colloquium stalwarts convened in the hallway. The speaker, Sheldon Zitner (English), used a trash can as a podium. In 1975-76 there were four dinners held at Hart House with talks by two professors from York, one from McMaster, and one from Toronto.

After the mid-1970s, the Colloquium, latterly heeding Warkentin's advice, abandoned general commensality. Since then, the TRRC has usually gathered in the late afternoon, with tea, coffee, and biscuits. Afterwards, the TRRC treats the speaker to dinner, along with one graduate student (usually but not always from the University of Toronto) who has close interest in the topic. And Colloquium discussion continues among those who choose to come along for the meal and pay their own way. 


\section{Building and collaborating}

As is evident in these pages, 1964 was a banner year for these studies in the Toronto area. As well as the founding of the TRRC, it saw the creation of its Bulletin and the establishment of the Centre for Reformation and Renaissance Studies (CRRS) at Victoria University in the University of Toronto. When in 1969 the TRRC Bulletin evolved into the journal Renaissance and Reformation $(R \& R)$, the CRRS and the TRRC were the two organizational founders; from 1977, other sponsoring groups joined. ${ }^{5}$

TRRC, CRRS, and R\&R have collaborated, both formally and informally, from the beginnings, yet they have also maintained distinct identities and structures. In various iterations, a representative from one group has often sat with the executive committee of another. For example, the TRRC executive committee included a delegate from $R \& R$ for many years, and the Chair (later Director) of the CRRS has been an ex officio member since 1972. Events, especially major ones, have often been co-sponsored and important visitors hosted by more than one group. And many individuals have participated in, and sometimes led, more than one of these bodies. These collaborations have been fertile indeed. And, though sometimes distinctions as to which group was doing what have been unclear to locals as well as to visitors, the multiplicity has strengthened the community of scholars and enriched Toronto's array of Renaissance and early modern activities.

These Toronto initiatives in the mid-1960s formed part of broader academic developments. At that time, interdisciplinarity/cross-disciplinarity/ multidisciplinarity were still regarded with considerable suspicion by some proponents of the existing departmental structures of teaching and research. Still, Europe's important cultural maturation between 1350 and 1750 attracted a growing interest in interdisciplinary scholarly conversation and inquiry. To these ends, the RSA had been founded in 1954. Elsewhere, the Centre d'études

\footnotetext{
5. Renaissance and Reformation was published as "() the Toronto Renaissance and Reformation Colloquium and the Victoria University Centre for Renaissance and Reformation Studies" until 1977. Then the New Series of Renaissance and Reformation/Renaissance et Réforme was inaugurated, and the Canadian Society for Renaissance Studies/Société Canadienne d'Études de la Renaissance and the North Central Conference of the RSA were added as sponsors. The Pacific Northwest Renaissance Conference (PNRC) joined as sponsor in 1984; in the next decade, the NCC-RSA ceased to exist, leaving four copyright holders: TRRC, CRRS, CSRS/SCÉR, and PNRC.
} 
supérieures de la Renaissance in Tours was founded in 1956 and the UCLA Center for Medieval and Renaissance Studies in 1962-63. In Canada, the Centre détudes de la Renaissance at the University of Sherbrooke followed in 1968, and the Canadian Society for Renaissance Studies/Société Canadienne d'Études de la Renaissance in 1976. The other major organization for period scholars, the Sixteenth Century Society and Conference, had its roots in Reformation studies; it launched in 1969 from the Concordia Lutheran Seminary in St. Louis. ${ }^{6}$

In particular, the TRRC has been an organizational associate of the RSA since 1968. It has regularly sent a representative to RSA Council; it also sponsors up to five sessions at the annual conference in the spring. Under the oversight of various TRRC chairs, and with special assistance from Konrad Eisenbichler, the Colloquium has over the years organized sessions on an array of topics-most recently, five sessions on "Erudites and Polymaths," organized by Eisenbichler for the 2014 meeting of the RSA.

The governing structure of the TRRC has evolved since 1964. A steering committee of eight members gave way within a few years to an executive committee of five, including a Chair, Secretary, and Treasurer, and an advisory committee. In the 1980s the original one-year term of the Chair was extended to two years. From then on, and at present, the TRRC executive should consist of the Chair, the Vice-Chair (who is expected to become the next Chair), the Secretary-Treasurer, the Programme Chair, the Past Chair, and the Director of CRRS ex officio.

Since 1968-69, when the TRRC structure instituted a Chair, twentynine persons have served of whom eight have been women. ${ }^{7}$ Most Chairs have been University of Toronto faculty members, from a wide range of departments and disciplines (English, French, Italian, Spanish, History, Art, History of Science). The first Chair from York University, in 1971-72, was C. Edward Rathé (French); much later, three other York faculty members-Jane Couchman (French, Humanities, Women's Studies), Elizabeth Cohen (History, Humanities) and Thomas Cohen (History, Humanities)-have chaired the Colloquium. No doubt for logistical reasons, the TRRC Chair has only once

6. Source: Scholarly Societies Project, University of Waterloo http://www.lib.uwaterloo.ca/society/1960_1969.html. Consulted March 6, 2014. Beginning in 2002, the name was changed to Sixteenth Century Society and Conference. The TRRC did not become an affiliate.

7. See Appendix: Chairs of the TRRC. 
come from a university outside the Greater Toronto Area; from 1995 to 1997, Graham Roebuck (English, McMaster) served as Chair.

In the early years (1964-74), members of the leadership committees came mainly from the University of Toronto, with four from York and one from Guelph. The Departments of History (7), English (6), French (6), and Italian (4) were the most frequently represented, with one member each from Art and Spanish. In keeping with its interdisciplinary and inter-university mission, the TRRC has always sought to reflect its varied constituencies, both on the executive and in choosing speakers for the Colloquium. Especially for the executive, it has not been easy to secure the optimum mix-not only of disciplines but also of representatives from different universities, and of different generations of scholars. Reflecting this continuing challenge, Ian Lancashire (English) wrote in March 1978 to express his concern that four of the seven members of the TRRC executive came from the Department of English. Furthermore, he argued, the committee should include two students, representatives from any three of Brock, Guelph, McMaster, Trent, Waterloo, Western, and York, and faculty representing at least English, History, Romance Languages, Medieval Studies, and Reformation Studies. This suggestion expresses well the TRRC's goals, but at different times these aspirations have proved difficult to implement fully, as faculty workloads and research demands have increased, especially for younger scholars.

As an independent organization, TRRC resources-and costs-have remained modest. Its small budget draws on membership fees. Membership is never required for participation, but is always encouraged, and represents mostly a gesture of commitment to the collective interest in Renaissance and early modern culture and to sustaining the lecture series for the benefit of the larger community. The annual fees have been low: they began at $\$ 1$ in the 1960 s, and rose to $\$ 6$ by the mid-1980s. Membership cost $\$ 12$ per year after 2000 , and at the organization's fiftieth birthday in 2014 it stands at $\$ 20$ for one year, \$55 for three years. The numbers of members has varied. Warkentin reports that there were more than one hundred names on Davis's initial list of local Renaissance and Reformation scholars. ${ }^{8}$ In 1970, the TRRC counted sixtyeight paid members. By the mid-1980s, the roster rose to between ninety-five

8. Germaine Warkentin in "Calling the World to Come and Share our Finds: Three Memoirs and Some Highlights from the Founding of Renaissance and Reformation," Natalie Zemon Davis, James McConica, and Germaine Warkentin, see above, p. 61. 
and one hundred. In 1992-93 it was again about seventy. In 2014, the paid-up membership is around forty.

The Colloquium over the years has drawn on resources-material and administrative-generously contributed by individuals and by various units of the University of Toronto, but it has never had an institutional budget or staff of its own. The support of CRRS has been vital. For many years, the Centre has provided the coffee and biscuits, as well as the time and talents of the Assistants to the Directors, who have designed posters and circulated publicity for TRRC talks, booked meeting rooms, and maintained membership and budget records. Recently, the TRRC executive, and especially the Secretary/Treasurer, have again shouldered many of these responsibilities. Thus, the Colloquium has run for fifty years on good will and volunteer efforts-of our institutional partners, of our leadership, and, importantly, of the many scholars whose talks make up the core of its program. The TRRC has not compensated speakers, nor routinely offered travel or accommodation expenses from its own, quite limited means. In keeping with the TRRC's mandate, most presenters have come from Toronto or its region, or have some other occasion to visit the city. Sometimes, however, the TRRC co-sponsors speakers whose expenses are funded by other academic units.

The Colloquium frequently collaborates with other units at the University of Toronto (and sometimes with other universities) to co-sponsor activities. By far the largest number of co-sponsorships-more than forty-have been with the CRRS. The TRRC has also co-sponsored speakers or other events with units such as the Departments of English, Art, French, History, Italian Studies, and Religion and the Centre for Medieval Studies. In the last several years, the TRRC has been seeking actively to expand its list of partners. Outside the University of Toronto, the Istituto Italiano di Cultura and the Erasmus of Rotterdam Society have been sponsors, as has the French Government.

The co-sponsorship model has allowed the TRRC to initiate or collaborate in a number of ad hoc scholarly gatherings on topics at the cutting edge of current research. Editorial issues inspired a workshop in 1978 on the "Preparation of Old Spelling Renaissance Play-texts in English," co-sponsored by the TRRC and held at Glendon College, York University. In 1980, a conference on "Exile and the Theme of Exile in the Renaissance," organized by Ken Bartlett and Jane Couchman and co-sponsored by the TRRC and CRRS, was also held at York; speakers hailed from the Universities of California-Berkeley, Concordia, and 
Toronto. In 1983 the TRRC presented an interdisciplinary conference, organized by Konrad Eisenbichler and Philip Sohm and funded by SSHRC, the Faculty of Arts, and several other units of the University of Toronto, on "The Language of Gesture in the Renaissance." Growing interest among Toronto colleagues in confraternity studies prompted the organization of "Ritual and Recreation in Renaissance Confraternities" in April 1989.

As the CRRS began with increasing regularity to stage substantial conferences in the fall of each year, the TRRC has continued as a co-sponsor. For example, in 2005 it supported "Creating Women: Notions of Femininity 1350-1700," organized by Manuela Scarci (Italian). At the same time, the Colloquium holds its own occasional special events. A 2006 mini-conference on "Ritual in Renaissance Rome" assembled local and visiting participants. In 2009, "Early Modern 'Relations': Genealogies and Hermeneutics," organized by Tom Cohen (History, York) and Germaine Warkentin (English, Toronto), featured the historian of Venice, Filippo De Vivo of Birkbeck College (London), and nine papers by local scholars. ${ }^{9}$ Again at the forefront of new scholarship, in fall 2012 the TRRC helped fund a workshop mounted by the Centre for Diaspora and Transnational Studies and the Department of History on "Genocidal Massacre in Early Modern Europe, Asia and the Americas." In April 2014 it co-sponsored another special event, organized by Nicholas Terpstra with his graduate students and guests from the Universities of Sydney and Chicago, that explored digital mapping to recover the experience of living in Renaissance Florence.

In 2014, two events were held to recognize the fiftieth anniversaries marked by this volume for collaborative Renaissance studies in Toronto. In June 2014 the TRRC co-sponsored with CRRS a large international conference organized by Mark Jurdjevic (Glendon, York). Titled "Rethinking Early Modernity: Methodological and Critical Innovation since the Ritual Turn," it revisited questions raised at TRRC's 1989 and 2006 mini-conferences. And in November, the TRRC hosted its own very lively, international celebration on the theme, central to its mission from the start, of "collegialities" in scholarship, both early modern and contemporary. 
Everyone is invited to attend TRRC events, and paid membership does not correlate with attendance. While the Colloquium audience fluctuates from talk to talk, there have usually been at least ten, and more typically twentyfive to thirty-five people attending a regular lecture. Special events, often cosponsored and featuring a prominent visitor, can draw much bigger crowds of one hundred and more. Most of the audience members are faculty members and graduate students, but some of the most faithful participants have been independent scholars, retirees, and others without institutional ties who just love to learn. Scholars from smaller units, or units with few colleagues working on the Renaissance and Reformation, have been particularly gratified to find common ground among Colloquium members. In the early years, when there were few other opportunities for such discussions, members would regularly attend papers on a wide range of topics. While there is still much overlap in attendance at Colloquium events, participants come increasingly from the speaker's own field, including his or her students. Graduate students and postdoctoral fellows, especially from the University of Toronto, have consistently played important roles in the TRRC as members and on the executive (as well as in the other interrelated Renaissance and Reformation groups and activities in the Toronto area). Many have kept in contact and returned to give TRRC talks in subsequent years, adding to the inter-institutional and multi-generational network of the Colloquium.

\section{Talking}

For fifty years the TRRC has had at the core of its activity a lecture series addressed not only to specialists but also to audiences with broad interests and open to multidisciplinary exploration. Presenting new inquiry and thoughtful revision on an expanding array of topics, TRRC speakers and their subjects have been richly diverse. ${ }^{10}$ Although as an itinerary, the sequence of talks may not track directly the many evolutions of the field, an overview of these developments helps frame the TRRC's wide terrain.

Over the fifty years of TRRC activity, the interdisciplinary academic fields of Renaissance and Reformation studies have evolved. Although for curriculum

10. This article offers a fairly detailed overview of TRRC speakers and other activities. But the archives are incomplete, and it is in any case impossible to mention every speaker, collaboration, or mini-conference. 
purposes the sequential coupling of Renaissance with Reformation became conventional, the two themes did not always sit easily together. From early on scholars debated the defining features of the Renaissance, including its relation to religion and the dates of its arrival in different parts of Europe. The Reformation, which initially meant mostly the Protestants, came to designate a broad band of religious transformations marked not only by theological differences but also by parallels of sensibility across confessional boundaries. As scholarship developed, both the Renaissance and Reformation terms seemed constraining to many, especially to those investigating wider political and especially social topics. New labels for the period began to circulate, notably the more encompassing, if still tendentious, "early modern." ${ }^{11}$ From the 1960s, historical studies in North America, energized in part by lively perspectives pioneered by the French journal, Annales. Economies, Sociétés, Civilisations, aimed to look at whole societies, to add investigations of the circumstances of lesser folk, rural and urban, and to explore a more anthropological view of cultural sharing and differentiation across social groups. From the 1970s-in a related momentum-the investigation of women and gender flourished as a major thread in Renaissance studies. More recently, the larger process pursued the globalization of early modern studies and the decentring of Europe. From the 1980s, other strands of French intellectual enterprise led research to focus again on language and culture. After 2000, cultural studies continued to mediate much scholarship about the Renaissance and early modern eras, including discussion of politics, society, and economy. These developments help situate the many and various discussions sponsored by the TRRC over the past fifty years.

The TRRC's mandate is to provide a framework for colloquy among scholars based in Ontario, Quebec, and nearby states. Happily, however, the TRRC has also benefitted from the presence in Toronto of important visiting scholars, often co-sponsored by other units. Speakers affiliated with the University of

11. Though they continued to bear rather narrow titles, the two premier journals of the field stretched their chronological span: Renaissance Quarterly (1300-1650) and Sixteenth Century Journal (14501648). Several more recently-launched journals adopted "early modern." The Journal of Medieval and Renaissance Studies was published from 1971 to 1995, after which it substituted "Early Modern" for "Renaissance" in its title. The interdisciplinary journal Early Modern Women chose that designation when it was founded in 2005. 
Toronto have given roughly half the TRRC talks. ${ }^{12}$ Thirteen Ontario universities and colleges have been represented, as well as five elsewhere in Canada, seven in New York State, and twenty-one in the rest of the United States. At least a dozen speakers have come from the United Kingdom, nine from France, and two from the Netherlands, as well as individual presenters from Belgium, Italy, and Israel. ${ }^{13}$

TRRC speakers are invited to talk about some aspect of their current research or new topics that they are beginning to open up. In any given year, the TRRC program has aimed for variety, both of methods and disciplines and of the settings from which sources come. The Colloquium has attracted many scholars who are interested in comparative and cross-disciplinary approaches to their material, and even when topics do have a primarily disciplinary focus, they are frequently of broader intellectual resonance. Over time, the majority of talks have been about England, and especially its literature, with both France and Italy supplying smaller but steady complements. Hispanic and Germanic cultures have been represented more sparsely.

Talks have almost always been given in English. Occasionally, however, and more often in recent years, talks by scholars from Quebec and from France have been delivered in French. For an early and fairly rare example, in October 1976, the Colloquium co-sponsored talks by several visitors from Quebec universities, including Claude Sutto (Montréal) on the assassination of Henri IV and J. M. de Bujanda (Sherbrooke) on links between literature and

12. Units of the University of Toronto represented: English, History, French, Italian, Spanish, Art, Music, Information Science, CRRS, the Institute for the History and Philosophy of Science and Technology, the Centre for Medieval Studies, the Pontifical Institute of Mediaeval Studies, the Centre for the Study of Drama, and the Records of Early English Drama project.

13. University affiliation of TRRC speakers from universities other than the University of Toronto, 1966-2014 (with best available numbers): Ontario: Brock (2), Carleton (5), Guelph (7), Laurentian (2), Laurier (2), McMaster (6), Queen's (4), St. Paul's (1), Trent (2), Waterloo (4), Western (5), Windsor (2), York (19). Rest of Canada: Concordia, McGill, Montréal, Caribou College, Simon Fraser, UBC, Victoria. New York State: Columbia, Fordham, NYU, Rochester, Syracuse, SUNY Buffalo, Union College. Rest of USA: California-Berkeley, Colby College, Cornell College, Cornell University, Detroit, Emory, Florida, Harvard, Haverford College, Johns Hopkins, Massachusetts-Amherst, Massachusetts-Boston, Michigan, North Carolina State, Northeastern Illinois, Notre Dame, Princeton, Occidental College, Texas, Weston School of Theology, Wisconsin, Yale. UK, Europe, and beyond: Cambridge, Courtauld, Kent, University of London, Warburg, York; Amsterdam, Brussels, Paris-Sorbonne, Paris-Nanterre, Tours, Poitiers, Toulouse, Udine; Haifa. 
the sixteenth-century Spanish Inquisition. TRRC's most frequent francophone guest was Jean-Claude Margolin, an eminent Erasmus scholar and Director of the Centre d'Études Supérieures de la Renaissance at the Université de Tours (1978-82); he spoke on Erasmus in 1982, on Charles Estienne, science, and humanism in 1990, and on the letters of Charles de Bouvelles in 2009. Since 2000, talks in French have been a bit more numerous. In 2003 Marie-Christine Pioffet (York) talked about Marc Lescarbot and geography, and Jean Céard (ParisNanterre) about the notion of culture in the Renaissance. From the University of Toronto, Benoît Bolduc (French) spoke in 2004 on pastoral poetry, and in 2009 Franco Pierno (Italian) discussed Italian Bibles.

From the beginning, the TRRC often enjoyed talks on high intellectual culture featuring great men and great ideas. The touchstone figure of Desiderius Erasmus has claimed special prominence in Toronto's interest in the pivotal era of the early sixteenth century. The focus on Erasmus had its roots in the bequest by Professor A. J. Bell to Victoria College of some thirty thousand books, including several hundred sixteenth- and seventeenth-century editions of works by Erasmus, humanist editions of the classics, and other early printed books. ${ }^{14}$ Responsibility for these books was vested in the newly-founded CRRS early in 1964, and they became the core of the CRRS library. Two years later, the Centre's first annual Erasmus Lecture was given by Wallace K. Ferguson. Shortly after that, the University of Toronto Press launched its ambitious publication project, the Collected Works of Erasmus in English, conceived by Ron Schoeffel. ${ }^{15}$ TRRC has often been able to take advantage of the visits to Toronto of CWE editors and other prominent Erasmus scholars from the USA and Europe, such as John C. Olin (Fordham) in 1984, Manfred Hoffmann (Emory) in 1989, Cornelis Augustijn (Amsterdam) in 1990, and Elaine Fantham (Princeton) in 1991. In the winter of 1995, the Colloquium co-sponsored a special series of four talks on Erasmian themes. Among them were two speakers from London: Michael Heath offered "The Batchelor and the Cuckolds: Erasmus on Love, Marriage, and Sex"; and Lisa Jardine spoke on, "Pen Friends and Patria: Erasmian Pedagogy and the Republic of Letters."

14. As James M. Estes has put it, "It all began with a question of what to do with Professor Bell's books." The First Forty Years: A Brief History of the Centre for Reformation and Renaissance Studies (Toronto: Centre for Reformation and Renaissance Studies, 2004), 11.

15. Fifty-six volumes to date, ongoing. The current chair of the CWE editorial board is James K. McConica. 
Europe's investment in humanist rhetoric and learning, so well exemplified by Erasmus, endures as an absorbing theme at the TRRC. History itself as a frame for Renaissance thought figured early on in papers by Brayton Polka (York) and Mark Phillips (Carleton). Erasmus's friend Thomas More was the topic for a talk by Arthur Kinney (Massachusetts) in 1978. More also figured in comparisons, considered with Machiavelli by Joseph Levine (Syracuse) in 1983, and with Milton by Rivkah Zim (Pembroke, Cambridge) in 1991. In 1983, the great Paul O. Kristeller (Columbia) lectured on "Petrarch's Place in the History of Learning." In the 1990s, some talks took up broad themes, such as James Hankins (Harvard) speaking on humanist political thought (1993). Several others chose a more limited focus: James Farge (Pontifical Institute of Mediaeval Studies) reflected on conservatism and humanism at the sixteenthcentury Collège de France (1991); Ari Wesseling (Amsterdam) talked about Angelo Poliziano and ancient rhetoric (1992); and Constant Mattheussen (KU Brussels) addressed humanism in Flanders (1997). In the 2010s several talks renewed attention to some of the classic themes of Renaissance intellectual history. Anthony D'Elia (Queen's) sought links between paganism and the soul of Sigismundo Malatesta, and Mark Jurdjevic (Glendon, York) presented a new perspective on political thought in Machiavelli's Florentine histories.

Print culture and book history have been central to the TRRC since the beginning. Its founders initiated the valuable finding-lists of rare books and pamphlets in the libraries of the University of Toronto and other nearby collections. ${ }^{16}$ Colloquium talks have pursued related themes. Notably, in 1978, Elizabeth Eisenstein (Michigan) offered a pre-publication taste of her influential The Printing Press as an Agent of Change. ${ }^{17}$ In the 1980s, collections and catalogues were addressed by Leonard Boyle (PIMS) concerning de Ricci's Census of Medieval and Renaissance Manuscripts (1982) and by Germaine Warkentin (English) on the library of the Sidney family at Penshurst (1986). Print culture in several languages has reclaimed TRRC attention quite recently. Gerard Dunnhaupt (Queen's) spoke on “Stultifera navis (1494): The World's First Bestseller" (2008); Antonio Ricci (York) discussed Venetian printers and editors of Orlando Furioso (2010); Marjorie Rubright (English) looked at

16. These were published in the TRRC bulletin and in early issues of $R \& R$. See the founders' statement and $R \hookleftarrow R$ history earlier in this issue.

17. Elizabeth Eisenstein, The Printing Press as an Agent of Change: Communications and Cultural Transformations in Early Modern Europe, 2 vols. (Cambridge: Cambridge University Press, 1979). 
Dutch black-letter editions of English playbooks and dictionaries (2011). In parallel, the Colloquium has heard postmodern interrogation of print culture and even queries as to its very survival. In 2004 Davide Panagia (Trent) offered "Typographical Biases, or the Noise of the Utterance," while in 2013 Neil Harris (Udine) insisted we face "The Elephant in the Room, or the Survival of Renaissance Books."

The history of science received attention from the TRRC in the 1970s and 1980s. In 1969, Stillman Drake (Institute for the History and Philosophy of Science and Technology) opened the discussion with a cross-disciplinary commentary on Renaissance music and science. Subsequently, talks by F. David Hoeniger (English; 1974), Jean-Claude Guédon (Montréal; 1974), Bert Hansen (IHPST; 1981), and Kim Veltman (IHPST; 1984) explored Renaissance science in England, France, and Italy from diverse perspectives. In 1988 Anthony Grafton (Princeton) looked further east with a lecture on Kepler as humanist and scientist in Rudophine Prague. More recently, Stephen Clucas (Birkbeck, London) explored Hobbes's notion of "computational" logic in natural philosophy (2011).

As its name declares, the TRRC has from the start been deeply interested in religion. Indeed, it is hard to study Europe in the fifteenth to seventeenth centuries-its politics or institutions or culture-without dealing with religious practice, the infinite ramifications of theological debate, and the too often bloody contestation that marked this era. While "Reformation"-standing alone as it does in the TRRC's name-in an earlier day designated specifically Protestant movements, the later use of a plural term "reformations" better reflects themes brought for discussion at the Colloquium. In early talks on the social contexts of Protestant reform, Stanford Reid (Guelph) described Scotland (1966) and Davis (History) spoke about France (1971). James Estes (History), with characteristic acerbity, titled his 1970 talk on Luther, Melanchthon, and the German princes "Chronic Sinners, Truculent Rulers, and Frustrated Theologians." Reformation themes continued to draw attention in the 1980s: Robert Kingdon (Wisconsin) debated "John Calvin: Theologian or Opportunist?" and McConica explained "Reformation and Reaction in Tudor Oxford" (1984). Extending inquiry about England, in particular, Anne Hutchinson (PIMS) presented the Bridgettine Nuns as a case study of Elizabethan recusancy (1995). Robert Tittler (Concordia) spoke in 1983, in 2005, and again in 2011, on English urban middle classes, their civic identities, and portraiture before, during, and after 
the Reformation. And in 1997 Vanessa Harding (London) compared funeral and burial practices in London and Paris in the era of religious reform. Ian Sloan, a research associate at the Northrop Frye Centre and a Fellow of the CRRS, combined those two pre-eminent Victoria University foci in his talk "Cheerfully Writing Off Protestantism: The Reverend Northrop Frye and the Reformation" in 2008.

In parallel, the prominent historian of Catholic reform John O'Malley (Detroit, then Weston School of Theology) spoke in 1975 on "Reform Thought at the Papal Court in the Early Sixteenth Century" and again in 1995 on "Trent and All That: 50 Years Trying to Name It." Several Ontario-based historians have, over the years, talked about the papacy, its court in Rome, and the trans-European politics that emanated from there. In 1974 Robert Toupin (Laurentian) lectured on the politics of Pope Gregory XIII. In 1978 and 1986, Kenneth Bartlett (History) laid out English maneuverings in Rome during the reigns of Queens Mary and Elizabeth. And in 1984 the genial Pierre Hurtubise (St. Paul's, Ottawa) described advice on how to succeed as a prelate at the court of a Renaissance pope. Also in the 1980s, two scholars from York University examined the very different minds of reformers: Rita Belladonna spoke about Bernardino Ochino and Tom Cohen about rank-and-file early Jesuits. Much later, in 2003, Simon Ditchfield (University of York) approached the papal city in the mode of cultural history with “'Time here becomes space': Reading Rome as a Sacred Landscape, ca. 1575-1635.” And Susan Rosa (Northeastern Illinois) in 2010 reflected on Catholic universalism and the conversion of Queen Christina of Sweden.

The Colloquium has heard many talks on government, politics, and public affairs in several European settings. The city of Florence has long been a favoured site for studying not only Renaissance culture but also public life. While social history flourished, Marvin Becker (Michigan) in 1979 lectured on "Florence, Its Society and Problems (1350-1480)," and Paula Clarke (McGill) in 1984 explained power through patronage among Florentine families. Twenty years later, in 2003, TRRC heard quite different approaches to the circulation of Florentine assets from Lawrin Armstrong (CMS) and from Christiane Klapisch-Zuber (Paris), long known for her path-breaking applications of anthropology to Italian sources.

Bridging from Florence to France, Edmund Beame (McMaster) spoke in 1975 on Machiavelli and the birth of the French secular state. In 1979, Davis, by 
then at Princeton, explored cultural mixing in "The Sacred and the Body Social in Sixteenth-Century Lyon." In the 1980s, the TRRC hosted several talks on the late medieval roots of French political structures. Julian Dent (History) spoke about the monarchy, and Jonathan Boulton (Notre Dame) about the creation of noble ranks. Looking from the bottom up, David M. Bessen (Cornell College) described the Jacquerie of 1358. Judicial structures policing not only violence but also transgressions of the mind and soul gathered increased scholarly interest. In 1988, Jonathan Pearl (History) introduced Jean Bodin's Demononamie; and, in 2007, Steven Bednarski (St. Jerome's, Waterloo) explored Provençal court records for more everyday crimes. Also, in the 2000s, two historians from France approached their past with cultural questions: Yves-Marie Bercé (ParisSorbonne) queried, "Did Henri IV Believe in Ghosts?" and Hervé Drévillon (Poitiers) asked, "How to Be a Hero in Seventeenth-Century France?"

England and the English appeared often in talks about the Protestant and Catholic reformations discussed earlier and about literary studies discussed below; the TRRC encountered other themes in English history as well. In 1978 the TRRC co-sponsored a lecture by the prominent social historian Lawrence Stone (Princeton) on the evolution of the early modern country house. On the cultural construction of authority, Paul Christianson (Queen's) talked in 1987 about James VI and I and royal self-fashioning, and Daniel Woolf (McMaster) spoke in 2000 on ancestry and honour.

Women and gender, new themes that captured wide interdisciplinary attention from the 1970s, came up for discussion by the Colloquium. After Davis first raised this flag in 1971, graduate student Nancy Adamson presented a prize-winning paper on women and humanist education in England (1980). Much later, in 2004, Joan Gibson (York) returned to Latinate woman in a talk on early modern Iberia. Twice in 1997, TRRC heard male scholars engaged in the "recovery" of women writers. In March, Jeremy Maule (Cambridge) argued for "Reinspecting 'Family Drama' before the Restoration, or, Women's Plays that were Performed." In October, Eisenbichler (Italian) described "The Many Faces of a Long Lost Woman: Laudomia Forteguerri, Poet, Muse, Mother, Lover, and Warrior." Other lectures looked at literary representations of women that held them up for praise and blame. In 1998 Larissa Taylor (Colby) examined the elusive gospel figure of Mary Magdalene, and in 2002 Manuela Scarci (Italian) introduced women as they appear in the novelle of Matteo Bandello. Brenda Hosington (Montréal) in 2004 and Renée-Claude Breitenstein (Brock) in 
2012 presented texts related to the querelle des femmes. Art historians Leatrice Mendelsohn (Union College) and Gabrielle Langdon (Western) explicated visual representations of women.

If less often than women, themes of masculinity and sexuality have likewise appeared at TRRC, especially in the late 1980s. Jacqueline Murray (Guelph) highlighted sexual bodies in papers on impotence (1986) and, more recently, "Misogyny, Masculinity and Mutilation" (2003). In a more idealizing vein, Massimo Ciavolella (Italian) explored "Eros and the Phantasms of Hereos" (1987). Eisenbichler took up the conjunction of masculinity and youth in "Boys will be Boys: The Children of the Archangel Raphael" (1989). In 1990 Patricia Vicari spoke to the evocative title: "Peacocks and Androgynes: Costume, Politics, and High Culture."

Another development in early modern studies has been the geographic and cultural de-centring of Europe, as scholars have looked both eastward to the Levant and westward to the Americas. Although one of the TRRC's earliest talks addressed the Ottoman empire (C. M. Kortepeter, 1965), most of the eastward vision has come after 9/11. Religion and, in particular, Catholic clergy figured prominently, as Europeans encountered eastern Christians, Muslims, and others who did not share their beliefs. Megan Armstrong (McMaster) in 2007 and Jean-Luc Nardonne (Toulouse) in 2010 discussed European visitors' representations of the Holy Land. More broadly, Natalie Rothman (History) explained the European construction of Levantine "otherness" (2007). And Selma Zecevic (York) in 2013 explored Muslim identities in early modern Ottoman Bosnia.

European ventures in the Americas and in what more lately came to be called the Atlantic world also figured in the TRRC's discussions. In a precocious venture into this domain, Jane Couchman (Glendon, York) in 1987 described aspects of the French colonial experience in Brazil. Talks on the New World then proliferated after 2000. The work of missionaries in Spanish America, and in particular the challenges of communication and translation, was the subject of three talks: Ken Mills (History) in 2005, Sanda Munjic (Spanish) in 2006, and Alan Durston (York) in 2008. Also in 2008, Germaine Warkentin (English) drew attention to more northerly colonies in "Aristotle in New France: Louis Nicholas, Jesuit Science and the Making of the Codex Canadensis." Most recently, historian Malcolm Smuts (Massachusetts, Boston) essayed a cultural history of the early modern Atlantic frontier. 
Nearly half the talks given at the TRRC have dealt with literary topics. English literature has been the most frequently discussed, followed by Italian and French, and, distantly, Spanish and Portuguese. There have been no talks on literatures in other European languages. Few talks, however, have been "purely" literary. Many have explored historical contexts, intersections with other disciplines, or comparative literature, while others have applied the techniques of literary studies to "non-literary" texts.

For English literature, theory was the focus for two papers in the 1970s. Annabel (Endicott) Patterson (then at York) reflected on "Ut pictura poesis: Some Implications for Renaissance Literary Theory" (1976) and A. C. Hamilton (Queen's) spoke "On the Concept of an English Literary Renaissance" (1977). Warkentin presented her work on English sonnet cycles by several authors in 1973 and 1982, as did Roger Kuin (York) in 1986. Many talks, however, focused on individual authors: in order of first appearance, Shakespeare (Wyman Herendeen, Windsor, 1985); Jonson (Brian Parker, English, 1972; Helen Ostovich, McMaster, 2003); Milton (Wyman Herendeen, Windsor, 1992); Marlowe (Donald Beecher, Carleton, 1983); Riche (Donald Beecher, 1990); Nashe (Michael Keefer, Guelph, 1998). Four talks on John Donne reflected very different approaches to his work: Kate Frost (Austin, Texas) configuring "Jack Donne and the School of Night" (1991); Tom Hester (North Carolina State) discussing his "Holy Sonnets" (1992); Elizabeth Harvey (English) approaching his "Elements" through the work of Luce Irigaray (2003); and Lynne Magnusson (English) analyzing his "language" through the fine structures of grammar and diction (2004). Apart from the literary canon, English political writings inspired several talks. In 1993 Joseph Black (English) spoke generally on pamphlet wars and the public sphere, and in 2004 Elizabeth Sauer (Brock) focused on one pamphlet in her "Tried by Print: Strafford and Laud in England's 'Sad Theatre.” Mary Nyquist (English) in 2002 explicated “The Tyrant's Stroke: Symbolic Violence in Early Modern Republicanism."

English drama is a perennially popular topic for the TRRC. Sheldon Zitner spoke in 1971 on dramatic form and two years later returned to explicate The Knight of the Burning Pestle. The work of the Records of Early English Drama (REED) project is reflected in talks by Alexandra Johnson on Tudor Corpus Christi plays (1986) and by David Klausner on the patronage of spectacle by William More, Prior of Worchester (1987). More recently, Holger Schott Syme identified some "Inconvenient Truths" from the contextual records for Shakespeare in the 1590s (2009). Paul Stevenson, talking on "Shakespeare and 
Globalization: The Merchant of Venice and the Work of Literary Criticism" (2005), illustrated some new critical trends, as did Paul Yachnin (McGill) discussing Thomas Middleton and the "Publicity of Space" as part his broader project Making Publics.

For the French literary Renaissance, surprisingly few TRRC talks have focused on specific texts among what are still regarded as the classics of the sixteenth century, and fewer yet on those of the seventeenth century. More often, speakers have taken comparative or interdisciplinary approaches. Gwenda Echard (York) looked at Ronsard and d'Aubigné in relation to the Erasmian ideal of kingship (1975), and Elaine Limbrick (University of Victoria) discussed Montaigne's scepticism in the broader context of French thinkers of his time (1981). François Paré (Guelph, then Waterloo) gave two talks nearly twenty years apart; in 1988, working with a canonical literary corpus he commented on "The Myth of Poverty in French Literature," and, in 2006, he explored "minority" languages and literatures as elements of "Linguistic Plurality in SixteenthCentury France."

Conversations about Italian literature, either on its own or in comparative studies, have a long, if intermittent, history at the TRRC. The epic Orlando $f u$ rioso claimed TRRC's regard on several occasions. In 1980 Paolo Valesio (Yale) set it in European context, and in 1981 Valerie Wise (NYU) spoke about the hero Ruggiero. In 1999, Giuseppe Mazzotta (Yale) returned to this poem in his comparative talk on Ariosto and Machiavelli. Well-known courtesy books were the choice of two speakers: Antonio Santossuoso (Western) on Giovanni Della Casa's Galateo (1973) and Olga Zorzi Pugliese (Italian) on the making of Castiglione's classic Il libro del Cortegiano (2004). Italian theatre, notably comedy, also inspired talks. In 1970, as a prologue to a performance of Ruzzante's play Bilora by students of the Drama Centre, Hannibal S. Noce (Italian) gave a talk on the playwright's Dialoghi in lingua rustica, and at a meeting later in the same year Michael Ukas (Italian) discussed the braggart in Italian Renaissance comedy. Many years later, in 2014, Rosalind Kerr (Alberta) described theatrical practice in "The Rise of the Diva on the Sixteenth-Century Commedia dell'Arte stage."

Portuguese and Spanish literary texts have figured infrequently at the TRRC. The only recorded talk on a Portuguese topic was in 1966, by Ralph Stanton (Waterloo) on epic poetry before 1700. A Spanish author first appeared in 1986, when Pedro León (Spanish) spoke on “Calderon's Divine Orpheus: 
Theological Paradox and Dramatic Spectacle." After 2000, Spanish literature, and Cervantes in particular, became more visible. That year Stephen Rupp (Spanish) lectured on soldiers and satire in Cervantes's El licendiado Vidriera, and in 2007 Ellen Anderson (York) discussed the same author's handling of compassion and comedy. Less canonical, the writings of the mystic and missionary Fray Juan de los Angeles provided material in 2006 for a talk by Sanda Munjic (Spanish).

Among the arts, music has been quite well represented, with many speakers adopting interdisciplinary or comparative methodologies. In 1966, Maria Rika Maniates (Music), one of the TRRC's earliest supporters, spoke on the double chanson in fifteenth-century France, with musical illustration performed by the Hortus Musicus; she returned in 1976 to explore Maniera as the central controversy in sixteenth-century music. Warren Drake (Music) offered a talk in 1971 on Ottaviano Petrucci and music printing, accompanied by motets sung by students in the Faculty of Music. In 1972 Bruce Bellingham (Rochester) spoke on Renaissance musical iconography, and in 1978 David Klausner (CMS) looked at English composers' encounters with Italian music in the sixteenth century. Ten years later, John Derkson (Knox) explained music for orators, and Timothy McGee (Music) described the socio-economic circumstances of late Renaissance musicians. Most recently, in 2009, David Fallis (Music; Toronto Consort) shared his expertise in directing and performing Renaissance music for twenty-first-century audiences.

Speakers on visual arts and architecture have also taken interesting cross-disciplinary or transnational approaches. In 1967, the TRRC heard one of its earliest eminent visitors, Anthony Blunt (Courtauld), speak twice-on "Classicism and the Baroque" and on Borromini. The next year W. McAllister Johnson (Art) and others arranged a symposium on French royal entries, a topic that he and Victor E. Graham (French), both active in the founding of the TRRC, developed into an interdisciplinary illustrated book. Other talks reflected the growing interest in the role of patrons. Egon Verheyen (Johns Hopkins) analyzed the inventive patronage of Federigo II Gonzaga, Duke of Mantua (1974); in 1979 Hendrik J. Horn (Guelph) looked at "Charles V and Vermeyen in Tunis, 1535"; and in 2000 Sheryl Reiss (Cornell) portrayed the Medici Pope Clement VII as a patron of art. Studies of Albrecht Dürer's humanism were presented by Philip Sohm (1979) and Joaneath Spicer (1983). Portraiture as a representation of identity and self-fashioning in historical context interested, 
among others, Joanna Woodall (Courtauld, 1995). The TRRC heard about Renaissance architecture only quite recently, but at a variety of sites. For the north, Myra Rosenfeld (Montreal) presented the Hotel de Cluny and the Abbot's palace in Paris (2005), and Matt Kavaler (Art) showed the distinctive Renaissance Gothic of northern Europe (2007). For Italy, Christy Anderson (Art) represented architecture as a network of practical logistics and human dynamics (2008), and Giancarla Periti (Art) spoke of Ravenna's layered monumental heritage in its Renaissance forms (2014).

\section{Concluding}

Given its mandate to offer a forum primarily for local and regional scholars and teachers, as well as for some visiting researchers, it is not surprising that the TRRC's fifty-year record reflects the diversity of Renaissance and Reformation scholarship rather than any specific intellectual program. Using many methods and posing new questions, the TRRC's speakers have explored a wide range of issues relating to the Renaissance, the reformations, and more broadly the early modern period in Europe and beyond. The Colloquium has welcomed new ideas and approaches, including comparative and transnational ones, and has encouraged the exploration of different theoretical paths. Among the speakers, some had already made major contributions to their fields and enjoyed international reputations; many others would join that company in subsequent years. Still others have contributed in less widely celebrated but equally important ways as scholar-teachers and students, and as listeners and discussants at Colloquium meetings.

Over the fifty years since the inception of the TRRC, in response to impulses similar to those that inspired Davis and McConica, a wide range of associations, including digital communities, have been created to facillitate scholarly collaboration. At the same time, the expansion and diversification of research foci for the early modern period may mean that scholars have less inclination to situate their work within broader interdisciplinary contexts and may no longer feel the sense of commonality experienced by the founders of the TRRC. In an era of great research possibilities but little time for contemplation, there is also rather less enthusiasm for undertaking the administrative tasks involved in chairing the Colloquium and arranging the lecture series. Yet those who do so benefit greatly from working with local fellow-scholars, and 
there has never been a dearth of scholars eager to present their work to the Colloquium nor of audience members eager to come together to participate in collegial discussion.

Looking retrospectively, then, the TRRC rightly claims an impressive record of collegiality, and will continue to support an evolving but sustained desire for interdisciplinary conversation into the foreseeable future. 


\section{Appendix \\ Toronto Renaissance and Reformation Colloquium Chairs}

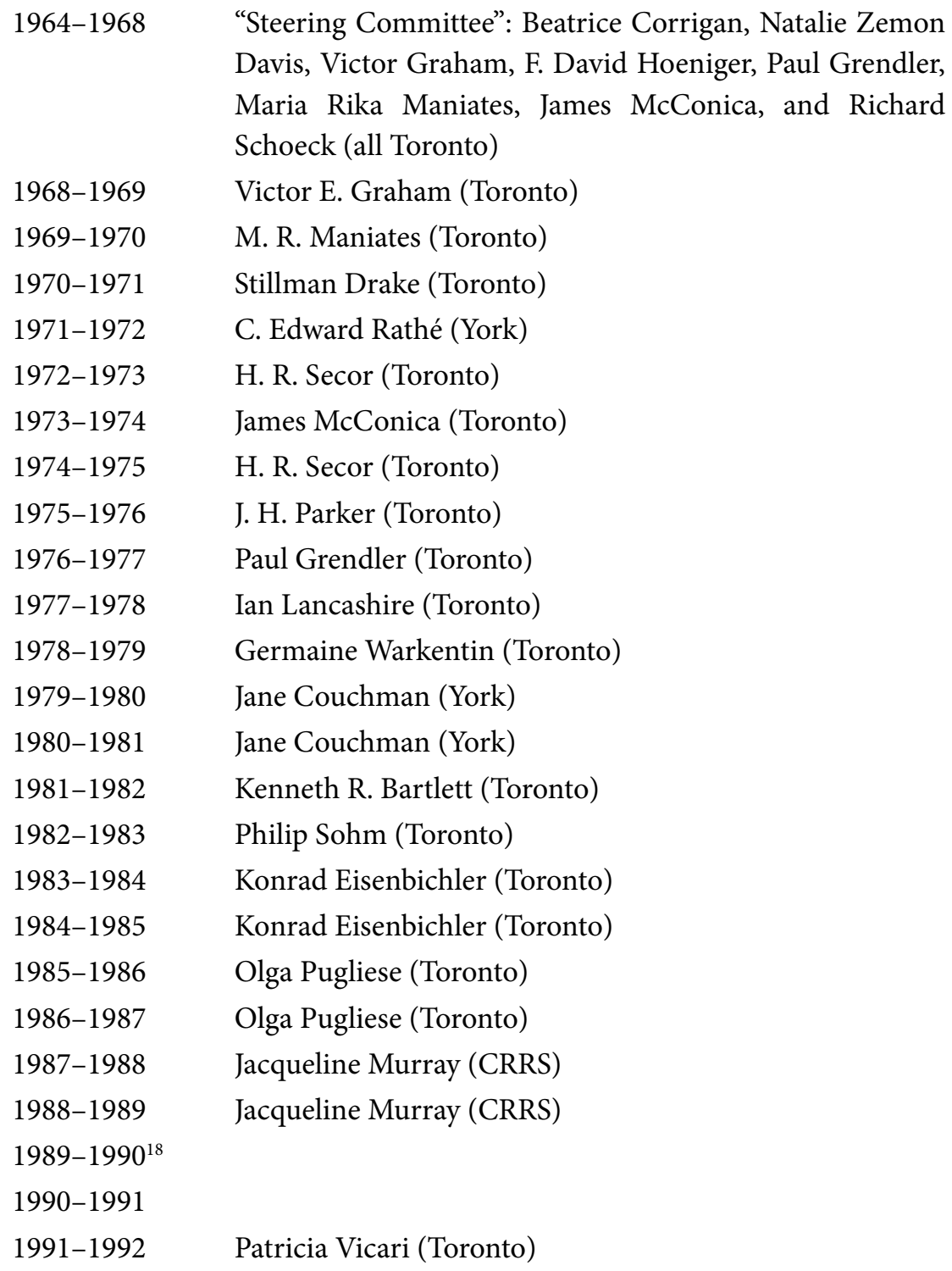

18. Neither personal nor institutional memory has so far yielded the name of the TRRC Chair from 1989-91. 


$\begin{array}{ll}\text { 1992-1993 } & \text { Patricia Vicari (Toronto) } \\ \text { 1993-1994 } & \text { David Galbraith (CRRS) } \\ 1994-1995 & \text { David Galbraith (CRRS) } \\ 1995-1996 & \text { Graham Roebuck (McMaster) } \\ 1996-1997 & \text { Graham Roebuck (McMaster) } \\ 1997-1998 & \text { Joseph Black (CRRS) } \\ 1998-1999 & \text { Joseph Black (CRRS) } \\ 1999-2000 & \text { Benoit Bolduc (Toronto) } \\ 2000-2001 & \text { Benoit Bolduc (Toronto) } \\ 2001-2002 & \text { Jane Couchman (York) } \\ 2002-2003 & \text { Jane Couchman (York) } \\ 2003-2004 & \text { Elizabeth Cohen (York) } \\ 2004-2005 & \text { Manuela Scarci (Toronto) } \\ 2005-2006 & \text { Manuela Scarci (Toronto) } \\ 2006-2007 & \text { Thomas Cohen (York) } \\ 2007-2008 & \text { Thomas Cohen (York) } \\ 2008-2009 & \text { Paul Cohen (Toronto) } \\ 2009-2010 & \text { Grégoire Holtz (Toronto) } \\ 2010-2011 & \text { Grégoire Holtz (Toronto) } \\ 2012 \text { (Jan-July) } & \text { Franco Pierno (Toronto) } \\ 2012-2013 & \text { Germaine Warkentin (Toronto) } \\ 2013-2014 & \text { Germaine Warkentin (Toronto) } \\ 2014-2015 & \text { Elizabeth Cohen (York) } \\ & \end{array}$

